Vol 01 No 02, 2021: 61-71

https://dx.doi.org/10.22334/jam.v1i2

Submitted $20^{\text {th }}$ Juni 2021

Accepted $10^{\text {th }}$ Agustus 2021

\title{
APLIKASI FILOSOFI TRI HITA KARANA DALAM PEMBERDAYAAN MASYARAKAT TONJA DI DENPASAR
}

\author{
Gede Yoga Kharisma Pradana \\ Institut Pariwisata dan Bisnis Internasional \\ yoga@stpbi.ac.id
}

\begin{abstract}
ABSTRAK
Tujuan penulisan artikel ini untuk mengkaji filosofi Tri Hita Karana dalam praktik pemberdayaan masyarakat Tonja. Pariwisata Bali tidak berkembang pesat di kelurahan Tonja, Denpasar. Dalam rangka membangun komitmen masyarakat Tonja, maka kegiatan pemberdayaan masyarakat Tonja mengadopsi filosofi Tri Hita Karana. Permasalahan dalam artikel ini berpusat pada : 1) Bagaimana bentuk rancangan kegiatan pemberdayaan masyarakat Tonja berbasis Tri Hita Karana dalam pembangunan pariwisata?.; 2) Bagaimana bentuk implementasi filosofi Tri Hita Karana dalam rangka pemberdayaan masyarakat Tonja sehubungan dengan pembangunan pariwisata?. Artikel ini diselesaikan secara kualitatif. Semua data berhasil dikumpulkan melalui studi pustaka dan proses observasi partisipasi di Denpasar. Semua data dianalisis secara kualitatif dengan teori simbol dan resepsi. Hasil menunjukan bahwa : 1) Filosofi Tri Hita Karana terimplementasi dalam program pengabdian masyarakat berlingkungan hijau, bersih dan sehat. Aplikasi filosofi Tri Hita Karana dalam rancangan kegiatan pemberdayaan masyarakat Tonja terlihat pada bagian pendahuluan, tujuan, khalayak sasaran dan susunan acara dalam usulan kegiatan pengabdian masyarakat berlingkungan hijau, bersih dan sehat. 2) Pengamalan filosofi Tri Hita Karana dilakukan melalui kegiatan bersih-bersih fisik, sosialisasi kebutuhan wisata, sumbangan alat kebersihan dan bibit tanaman serta melakukan persembahyangan bersama di kelurahan Tonja sebagai usaha untuk mewujudkan lingkungan kelurahan Tonja yang bersih, hijau, sehat serta kondusif untuk perkembangan pariwisata.
\end{abstract}

Kata Kunci : Filosofi Tri Hita Karana, Pariwisata Bali, Masyarakat Tonja.

\section{APPLICATION OF THE THK PHILOSOPHY IN EMPOWERING TONJA SOCIETY IN DENPASAR}

ABSTRACT

The purpose of writing this article is to examine the philosophy of Tri Hita Karana in the practice of empowering the Tonja society. Tourism in Bali is not growing rapidly in the Tonja village. In order to build the commitment of the people of Tonja in the tourism sector, the Tonja people empowerment activities adopted the Tri Hita Karana. The problems are: 1) What is the form of the Tonja community empowerment design based on Tri Hita Karana? 2) What is the form of Tri Hita Karana implementation for the empowerment of the people of Tonja?. This article was 
completed qualitatively. All data were collected through literature study and participatory observation processes in Denpasar. All data were analyzed qualitatively. The results: 1) The Tri Hita Karana application in the design of the Tonja community empowerment activities can be seen in the introduction, objectives, target audience and schedule of the proposed community service with a green, clean and healthy environment. 2) The Tri Hita Karana practice can be seen in physical cleanup activities, tourism socialization, donation of cleaning tools for plant seeds, and praying together as an effort to create a clean, green, healthy and conducive environment for the Tonja village to develop tourism.

Keywords : The Philosophy of Tri Hita Karana, Bali Tourism, the People of Tonja.

\section{PENDAHULUAN}

Bali dikenal sebagai pulau dewata. Sebutan pulau dewata tidak lepas dari keberadaan ribuan pura dan beragam tradisi budaya Bali (Dewi, 2016). Beragam tradisi budaya Bali hidup berdampingan secara harmonis sejak lama sejalan dengan tradisi agama Hindu Bali yang mengaggungkan banyak nama dewa dalam beragam upacara agama Hindu di pura. Keharmonisan tradisi agama Hindu Bali dalam beragam tradisi budaya Bali diantaranya tercipta atas pemahaman masyarakat Bali atas filosofi Tri Hita Karana (Pradana dan Pratiwi, 2020). Demikian filosofi Tri Hita Karana dipandang sebagai bagian dari kearifan lokal dari masyarakat Bali (Pranajaya, 2019).

Masyarakat Bali diketahui sebagai kelompok sosial yang sukses dalam pembangunan pariwisata di pulau Bali. Pulau Bali pun semakin terkenal secara internasional setelah kesuksesan pembangunan pariwisata (Tejayadi dkk, 2019). Pariwisata Bali dikenal berkembang pesat di level internasional (Rideng dkk, 2020). Pariwisata Bali merupakan bidang produktif andalan nasional, terbaik sekaligus menjadi salah satu kiblat pembangunan pariwisata di Indonesia (Syah dan Hajarrahmah, 2019). Pariwisata Bali terkenal sejalan dengan kesuksesan pengembangan varian paket wisata budaya yang menjadi favorit dikalangan wisatawan.

Kesuksesan pembangunan pariwisata budaya sudah berkontribusi besar terhadap terciptanya citra Bali sebagai destinasi wisata favorit dunia. Demikian paket wisata budaya Bali menjadi paket favorit bagi para wisatawan ketika berwisata di Bali (Pradana dan Parwati, 2017). Melalui beberapa paket wisata budaya Bali, para wisatawan dapat berkesempatan mengenal tentang kearifan lokal dalam masyarakat Bali yang terbangun berdasarkan prinsip filosofi Tri Hita Karana.

Prinsip filosofi Tri Hita Karana dapat dipahami sebagai suatu basis dalam pengelolaan dan pengembangan paket wisata budaya Bali yang sudah terkenal secara internasional. Demikian model pembangunan pariwisata Bali menjadi suatu kiblat dalam pembangunan pariwisata nasional (Johana dkk, 2020). Begitu pentingnya makna filosofi Tri Hita Karana untuk perkembangan pariwisata, maka Institut Pariwisata dan Bisnis Internasional (IPBI) selaku institusi pendidikan tinggi sudah berusaha mengaplikasikan filosofi Tri Hita Karana di sektor pendidikan. Hingga tahun 2021, terbukti bahwa IPBI dinyatakan telah lulus akreditasi Tri Hita Karana dan berhasil meraih penghargaan Gold, Emerald dan Platinum (IPBI, 2021). Raihan penghargaan Tri Hita Karana ini merupakan suatu misi institusi dalam rangka membangun kualitas pendidikan secara nasional dan Internasional. Hal itu sejalan dengan visi Institut 
Pariwisata dan Bisnis Internasional untuk menjadi institusi pendidikan tinggi di bidang pariwisata dan bisnis yang berkualitas unggul dan mampu bersaing secara secara nasional dan internasional (IPBI, 2021).

Dalam rangka mewujudkan visi Institut Pariwisata dan Bisnis Internasional, maka aplikasi program pemberdayaan dan pengabdian masyarakat merupakan sebuah prioritas pilihan yang ditempuh dosen selaku civitas akademika Institut Pariwisata dan Bisnis Internasional untuk mempertahankan maupun meningkatkan kualitas pendidikan serta kualitas perkembangan pariwisata. Pelaksanaan pengabdian kepada masyarakat dipandang civitas akademika Institut Pariwisata dan Bisnis Internasional sebagai sebuah kewajiban dosen dalam meningkatkan manfaat praktis dari proses pembelajaran ilmu pariwisata. Oleh karenanya, peranan dosen dalam aplikasi program pemberdayaan dan pengabdian masyarakat bukanlah sesuatu yang spesial di Institut Pariwisata dan Bisnis Internasional. Namun, luaran proses kegiatan itu selalu dinanti oleh para civitas akademika Institut Pariwisata dan Bisnis Internasional.

Sehubungan dengan penghayatan makna filosofi Tri Hita Karana dalam perkembangan pariwisata, civitas akademika Institut Pariwisata dan Bisnis Internasional pernah terlibat dalam pelaksanaan suatu program pengabdian masyarakat di kelurahan Tonja, Denpasar (Litabmas, 2017). Aplikasi program pengabdian masyarakat berdasarkan prinsip filosofi Tri Hita Karana di kelurahan Tonja, Denpasar dilakukan mengingat pariwisata Bali tidak berkembang pesat di kelurahan Tonja, Denpasar. Sangat jarangnya terlihat kegiatan wisatawan dan minimnya sarana akomodasi yang bersifat mendukung perkembangan pariwisata Bali, maka aplikasi filosofi Tri Hita Karana dalam pelaksanaan program pengabdian kepada masyarakat Tonja menjadi prioritas dalam pemberdayaan dan membangun komitmen bersama terhadap kualitas daya tarik wisata. Adapun permasalahan utama sehubungan dengan aplikasi filosofi Tri Hita Karana dalam rangka pemberdayaan masyarakat Tonja difokuskan pada : a) Bagaimana bentuk rancangan kegiatan pemberdayaan masyarakat Tonja berbasis Tri Hita Karana dalam pembangunan pariwisata Bali?; b) Bagaimana bentuk implementasi filosofi Tri Hita Karana dalam rangka pemberdayaan masyarakat Tonja dalam pembangunan pariwisata Bali?.

\section{METODE}

Pengkajian tentang aplikasi filosofi Tri Hita Karana untuk pemberdayaan masyarakat Tonja dalam pembangunan pariwisata Bali di Denpasar dilakukan dengan mempergunakan metode kualitatif. Metode kualitatif merupakan metode penelitian yang beroperasi berdasarkan analisis kualitatif dan bantuan data kualitatif (Berg dan Lune, 2018). Data kualitatif dapat diperoleh melalui observasi dan wawancara dengan informan (Patton, 2015). Data primer berhasil dikumpulkan melalui observasi partisipasi selama proses kegiatan pemberdayaan masyarakat Tonja di Denpasar. Data sekunder dalam artikel ini dikumpulkan melalui studi pustaka terhadap filosofi Tri Hita Karana dan Pariwisata Bali. Total data berhasil dianalisis secara kualitatif dengan mempergunakan teori simbol dan teori resepsi.

Proses penyusunan artikel tentang aplikasi filosofi Tri Hita Karana untuk pemberdayaan masyarakat Tonja dalam pembangunan pariwisata Bali di Denpasar dapat dilakukan setelah terlibat dalam kegiatan pemberdayaan masyarakat Tonja di Denpasar. Kegiatan pemberdayaan masyarakat dipusatkan pada kelurahan Tonja di Denpasar 
dengan pertimbangan : 1) Pariwisata Bali berkembang dengan sangat baik di wilayah Bali Selatan; 2) Pariwisata Bali kurang berkembang baik di wilayah Bali Selatan seperti di kelurahan Tonja, Denpasar; 3) kelurahan Tonja berlokasi dekat dengan IPBI; 4) Masyarakat Tonja adalah Masyarakat Bali yang berdomisili di kelurahan Tonja, Denpasar. Masyarakat Tonja dominan beragama Hindu dan sudah mengenal dengan sangat baik tentang hakekat Tri Hita Karana; 5) Masyarakat Tonja merespon positif usulan kegiatan pengabdian dan pemberdayaan masyarakat dalam rangka pembangunan pariwisata Bali.

Bali dikenal memiliki kegotong-royongan dan kepemimpinan lokal yang bersifat sentral dalam pembangunan daerah (Humaedi dkk, 2021). Berdasarkan situasi dan usulan kegiatan pemberdayaan masyarakat Tonja di Denpasar, maka telah disepakati oleh semua partisipan bahwa kegiatan dapat dilakukan pada area Pura Beji, Pura Puseh dan Pura Dalem Tonja di Denpasar. Kegiatan ini dapat diketahui berlangsung dengan berpusat pada adanya aktivitas pemberdayaan masyarakat Tonja di sekitar Pura Beji, Pura Puseh dan Pura Dalem Tonja di Denpasar. Melalui bukti aktivitas pemberdayaan masyarakat Tonja di Denpasar, maka pengkajian tentang aplikasi filosofi Tri Hita Karana dapat diselesaikan dalam bentuk artikel.

\section{HASIL DAN PEMBAHASAN}

\section{Rancangan Kegiatan Pemberdayaan Masyarakat Tonja Berbasis Tri Hita Karana Dalam Pembangunan Pariwisata Bali}

Rancangan ini dapat terealisasi berkat partisipasi serta dukungan para civitas akademika Sekolah Tinggi Pariwisata Bali Internasional (Litabmas, 2017). Institut Pariwisata dan Bisnis Internasional yang sebelumnya disebut Sekolah Tinggi Pariwisata Bali Internasional sebelum tahun 2020 sudah berhasil membangun sebuah rancangan kegiatan pemberdayaan masyarakat Tonja berbasis Tri Hita Karana disusun oleh tim litabmas IPBI dalam rangka pengabdian kepada masyarakat dengan pertimbangan kebutuhan masyarakat, kebutuhan dan kemampuan para dosen serta kapasitas institusi. Komponen struktur dibutuhkan dalam proses mengatur dan menunjang tahapan kegiatan (Hyland dan Bateman, 2004; Triguna, 2004; Dharmika dan Pradana, 2020). Rancangan kegiatan pemberdayaan masyarakat Tonja berbasis Tri Hita Karana ini terdiri dari komponen struktur usulan pendahuluan, tujuan, khalayak sasaran, luaran, anggaran, peserta, metode pelaksanaan, agenda kegiatan dan peta kegiatan (Litabmas, 2017). Sasaran utama dari kegiatan pemberdayaan masyarakat Tonja sehubungan dengan pembangunan pariwisata adalah menciptakan lingkungan hijau, bersih dan sehat di Tonja serta kondusif untuk pengembangan pariwisata Bali. Oleh karena itu, kegiatan pengabdian kepada masyarakat Tonja ini dikenal dengan program pengabdian masyarakat berlingkungan hijau, bersih dan sehat. Lingkungan hijau, bersih dan sehat diperlukan dalam pariwisata berkelanjutan. Lingkungan hijau, bersih dan sehat juga merupakan beberapa harapan masyarakat Tonja selama pengamalan filosofi Tri Hita Karana dalam konteks budaya.

Aplikasi Filosofi Tri Hita Karana dalam rancangan kegiatan pengabdian kepada masyarakat Tonja tersirat pada hampir setiap komponen struktur usulan kegiatan. Manifestasi nilai perlu diabstraksikan dalam uraian unsur praktik (Triguna, 2004; Holub, 
2003; Dharmika dkk, 2020). Nilai-nilai Tri Hita Karana dalam rancangan program kegiatan kepada masyarakat berlingkungan hijau, bersih dan sehat di Tonja, Denpasar dapat disimak pada matrix berikut.

\begin{tabular}{|c|c|c|c|c|}
\hline \multirow[t]{2}{*}{ No. } & \multirow{2}{*}{$\begin{array}{l}\text { Rancangan } \\
\text { Program } \\
\text { Lingkungan } \\
\text { Hijau, Bersih } \\
\text { dan Sehat }\end{array}$} & \multicolumn{3}{|c|}{ Filosofi Tri Hita Karana } \\
\hline & & Parahyangan & Pawongan & Palemahan \\
\hline 1. & Pendahuluan & $\begin{array}{l}\text { Area suci di Pura } \\
\text { kelurahan Tonja. }\end{array}$ & $\begin{array}{l}\text { Civitas } \\
\text { Akademia IPBI } \\
\text { dan Masyarakat } \\
\text { Tonja. }\end{array}$ & $\begin{array}{l}\text { Lingkungan kelurahan } \\
\text { Tonja. }\end{array}$ \\
\hline 2. & Tujuan & - & $\begin{array}{l}\text { Meningkatkan } \\
\text { kepedulian } \\
\text { Civitas } \\
\text { Akademika IPBI } \\
\text { terhadap } \\
\text { masyarakat dan } \\
\text { dinamika } \\
\text { pariwisata. }\end{array}$ & $\begin{array}{l}\text { Peningkatan } \\
\text { Kebersihan dan } \\
\text { kelestarian lingkungan } \\
\text { sebagai modal } \\
\text { pengembangan daya } \\
\text { tarik wisata. }\end{array}$ \\
\hline 3. & $\begin{array}{l}\text { Khalayak } \\
\text { Sasaran }\end{array}$ & $\begin{array}{l}\text { Kebersihan area } \\
\text { suci di Pura Beji, } \\
\text { Pura Puseh dan } \\
\text { Pura Dalem. }\end{array}$ & $\begin{array}{l}\text { Masyarakat } \\
\text { Tonja dan calon } \\
\text { pelaku wisata. }\end{array}$ & $\begin{array}{l}\text { Penghijauan dan } \\
\text { kebersihan lingkungan } \\
\text { kelurahan Tonja. }\end{array}$ \\
\hline 4. & Luaran & $\begin{array}{l}\text { Donasi kepada } \\
\text { masyarakat Tonja } \\
\text { untuk } \\
\text { pemeliharaan dan } \\
\text { peningkatan } \\
\text { kualitas } \\
\text { kebersihan dan } \\
\text { kesucian Pura di } \\
\text { kelurahan Tonja. }\end{array}$ & $\begin{array}{l}\text { Perluasan } \\
\text { wawasan } \\
\text { tentang } \\
\text { lingkungan } \\
\text { kondusif untuk } \\
\text { perkembangan } \\
\text { pariwisata } \\
\text { diantara } \\
\text { Masyarakat } \\
\text { Tonja dan } \\
\text { Civitas } \\
\text { Akademika } \\
\text { IPBI. }\end{array}$ & $\begin{array}{l}\text { Bibit tanaman baru dan } \\
\text { kebersihan lingkungan } \\
\text { kelurahan Tonja. }\end{array}$ \\
\hline 5. & Anggaran & Dana punia. & - & $\begin{array}{l}\text { Bibit tanaman hias dan } \\
\text { Tong Sampah. }\end{array}$ \\
\hline 6. & Peserta & - & $\begin{array}{l}\text { Civitas } \\
\text { Akademika } \\
\text { IPBI. }\end{array}$ & - \\
\hline
\end{tabular}




\begin{tabular}{|c|c|c|c|c|}
\hline 7. & $\begin{array}{l}\text { Metode } \\
\text { Pelaksanaan }\end{array}$ & $\begin{array}{l}\text { Observasi di area } \\
\text { Pura kelurahan } \\
\text { Tonja. }\end{array}$ & $\begin{array}{l}\text { Penugasan } \\
\text { Civitas } \\
\text { Akademika } \\
\text { IPBI. }\end{array}$ & $\begin{array}{l}\text { Observasi } \\
\text { lingkungan } \\
\text { Tonja. }\end{array}$ \\
\hline 8. & $\begin{array}{l}\text { Agenda } \\
\text { Kegiatan }\end{array}$ & $\begin{array}{l}\text { Persembahyangan } \\
\text { bersama, } \\
\text { pemberian donasi } \\
\text { dan pembersihan } \\
\text { sampah di area } \\
\text { Pura kelurahan } \\
\text { Tonja. }\end{array}$ & $\begin{array}{l}\text { Laporan ketua } \\
\text { panitia, } \\
\text { sambutan } \\
\text { kegiatan dari } \\
\text { IPBI-Lurah desa } \\
\text { Tonja, kepala } \\
\text { desa adat Tonja- } \\
\text { koordinator } \\
\text { pengempon } \\
\text { pura, sosialisasi } \\
\text { kegiatan } \\
\text { pariwisata. }\end{array}$ & $\begin{array}{l}\text { Pembersihan sampah, } \\
\text { Pembersihan rumput- } \\
\text { rumput liar dan } \\
\text { penanaman } \\
\text { tanaman hias pada } \\
\text { pekarangan kelurahan } \\
\text { Tonja. }\end{array}$ \\
\hline 9. & Peta Kegiatan & $\begin{array}{l}\text { Pura Beji, Pura } \\
\text { Desa, Pura Dalem } \\
\text { kelurahan Tonja. }\end{array}$ & - & $\begin{array}{l}\text { Pekarangan kelurahan } \\
\text { Tonja. }\end{array}$ \\
\hline
\end{tabular}

Gambar 1. Matrix Tri Hita Karana Pada Rancangan Program Pengabdian Kepada Masyarakat Berlingkungan Hijau, Bersih dan Sehat di Tonja Denpasar

Berdasarkan matrix tersebut maka dapat dipahami bahwa rancangan program pengabdian kepada masyarakat berlingkungan hijau, bersih dan sehat merupakan sebuah bentuk implementasi nilai-nilai Tri Hita Karana. Hakekat nilai termaknai ketika terimplementasi dan diresepsi menjadi bagian dari suatu praktik (Holub, 2003; Azis dan Huda, 2020; Humaedi dkk, 2021; Muis dkk, 2020). Unsur filosofi Tri Hita Karana dapat diketahui teraplikasi secara sempurna pada bagian pendahuluan, khalayak sasaran, luaran, metode pelaksanaan dan agenda kegiatan dalam rancangan program lingkungan hijau, bersih dan sehat di kelurahan Tonja, Denpasar.

\section{Aplikasi Filosofi Tri Hita Karana Dalam Rangka Pemberdayaan Masyarakat Tonja Dalam Pembangunan Pariwisata Bali}

Kegiatan pemberdayaan masyarakat sudah sepantasnya dirancang berdasarkan potensi dan kemampuan masyarakat (Muis dan Heksa, 2020). Berdasarkan potensi wisata dan kesepakatan dengan masyarakat di kelurahan Tonja Denpasar, maka kegiatan pengabdian kepada masyarakat berdasarkan program lingkungan hijau, bersih dan sehat berpusat pada area Pura Beji, Pura Desa dan Pura Dalem (Litabmas, 2017). Area Pura Beji, Pura Desa dan Pura Dalem kelurahan Tonja Denpasar dipilih berdasarkan masalah kebersihan sampah dan lingkungan serta dipilih berdasarkan perizinan dari lurah desa Tonja dan ketua penelitian-pengabdian masyarakat IPBI. Kegiatan pengabdian masyarakat yang dilakukan disekitar Pura Beji, Pura Desa dan Pura Dalem di kelurahan Tonja Denpasar merupakan bentuk pengamalan pengetahuan pariwisata dan filosofi Tri Hita Karana untuk masyarakat Tonja dan perkembangan 
pariwisata Bali. Sebagaimana suatu praktik dapat diresepsi sebagai bentuk manifestasi tanggapan atas pemahaman simbolik maupun teks dalam suatu peristiwa (Endaswara, 2003; Holub, 2003).

Filosofi Tri Hita Karana diketahui teraplikasi dalam kegiatan pengabdian masyarakat berdasarkan program lingkungan hijau, bersih dan sehat di kelurahan Tonja Denpasar melalui proses realisasi kegiatan. Realisasi menegaskan respon konkret terhadap ideologi maupun kepentingan (Pradana, 2012; Pradana, 2018; Azis dan Huda, 2020; Pradana dkk, 2016). Realisasi kegiatan program lingkungan hijau, bersih dan sehat di kelurahan Tonja Denpasar sebagai bentuk kepedulian terhadap masyarakat dan kontribusi pariwisata dimulai dengan kegiatan observasi dari para civitas akademika di sekitar kampus IPBI. Hasil observasi lokasi kegiatan kemudian didiskusikan bersama dan diputuskan memilih kelurahan Tonja Denpasar berdasarkan masalah pariwisata, keterbukaan masyarakat dan kesiapan civitas akademika IPBI. Langkah selanjutnya kemudian observasi lanjutan di kelurahan Tonja Denpasar untuk mendapatkan persetujuan dari lurah, bendesa adat dan pemangku pura dalem di kelurahan Tonja Denpasar sehubungan dengan usulan kegiatan program lingkungan hijau, bersih dan sehat di kelurahan Tonja. Usulan kegiatan pengabdian masyarakat berdasarkan program lingkungan hijau, bersih dan sehat di kelurahan Tonja Denpasar meliputi agenda pembuatan denah lokasi kegiatan, pembagian partisipasi dan pengumpulan peralatan kegiatan diselesaikan setelah mendapatkan persetujuan dari kepala desa, bendesa adat, pemangku pura dalem di kelurahan Tonja Denpasar serta ketua penelitian dan pengabdian masyarakat IPBI.

Kesesuaian dan kesepahaman partisipan terhadap orientasi nilai budaya dapat menjadi basis dalam terwujudnya praktik sosial (Holub, 2003). Pada tahap persiapan kegiatan ini, aplikasi dari orientasi nilai parahyangan dalam filosofi Tri Hita Karana terwujud ketika proses pencarian konfirmasi usulan kegiatan dari pemangku pura dalem kelurahan Tonja, aplikasi dari orientasi nilai pawongan dalam filosofi Tri Hita Karana terlihat ketika proses pencarian konfirmasi usulan kegiatan dari bendesa adat dan lurah Tonja Denpasar serta aplikasi dari orientasi nilai palemahan dalam filosofi Tri Hita Karana termanifestasi sejak penentuan lokasi kegiatan dan identifikasi kebutuhan kegiatan selama observasi lanjutan di kelurahan Tonja Denpasar dalam rangka penyusunan usulan program kegiatan pengabdian masyarakat IPBI.

Kegiatan pengabdian masyarakat di kelurahan Tonja berdasarkan program lingkungan hijau, bersih dan sehat dilaksanakan sejak pukul 07.00 wita selama dua hari, tepatnya pada tanggal 4 Agustus dan 5 Agustus 2017 di kelurahan Tonja Denpasar (Litabmas, 2017). Pada tanggal 4 Agustus 2017, dilakukan upacara persembahyangan bersama disertai pembukaan kegiatan pengabdian kepada masyarakat disertai dengan penyerahan bantuan berupa tong sampah, dana punia dan bibit tanaman puring, tanaman bunga sandat, tanaman bunga cempaka, tanaman bunga kembang sepatu dan tanaman kelapa. Setelah acara peresmian kegiatan selesai dilakukan sosialisasi tentang pariwisata Bali.

Pada tanggal 5 Agustus 2017 dilakukan kegiatan kerja bakti dalam rangka menciptakan lingkungan hijau, bersih dan sehat yang kondusif untuk perkembangan pariwisata di kelurahan Tonja Denpasar. Kegiatan dimulai dengan upacara persembahyangan bersama, kemudian dilakukan kegiatan pembersihan sampah, penanaman bibit tanaman hias dan pembersihan rumput-rumput liar pada pekarangan disekitar Pura Beji, Pura Desa dan Pura Dalem di kelurahan Tonja Denpasar. Setelah 
kegiatan kerja bakti selesai, kegiatan pengabdian masyarakat berdasarkan program lingkungan hijau, bersih dan sehat di kelurahan Tonja ditutup dengan persembahyangan bersama dan diskusi tentang pariwisata Bali.

Aplikasi unsur budaya dapat diketahui melalui spesialisasi ruang praktik dan atribut. Selama kegiatan penerapan program lingkungan hijau, bersih dan sehat dalam rangka pengabdian dan pemberdayaan masyarakat Tonja sejalan dengan perkembangan pariwisata Bali dapat disimak bahwa sudah teraplikasinya unsur-unsur filosofi Tri Hita Karana. Orientasi nilai parahyangan dapat diketahui melalui kegiatan persembahyangan bersama di Pura kelurahan Tonja Denpasar, sumbangan alat kebersihan, dana punia untuk kesucian pura dan peningkatan kualitas kebersihan area pura dan kegiatan kerja bakti di area pura kelurahan Tonja Denpasar. Sedangkan orientasi nilai pawongan termanifestasi pada kegiatan sosialisasi dan diskusi tentang pariwisata Bali, melibatkan anggota masyarakat Tonja selama kegiatan bersih-bersih di lingkungan Tonja Denpasar, selama kegiatan pembukaan, penyerahan donasi dan penutupan acara pengabdian masyarakat selalu menghadirkan perwakilan dari kelurahan, pengurus adat dan pemangku pura di kelurahan Tonja. Sejalan dengan itu, aplikasi dari orientasi nilai palemahan terlihat pada kegiatan penanaman bibit tanaman hias dan bersih-bersih di pekarangan kelurahan Tonja Denpasar.

\section{Pembahasan}

Filosofi Tri Hita Karana merupakan suatu manifestasi dari kearifan lokal Bali. Tiga sumber penyebab kebahagiaan kehidupan manusia yang diyakini orang Bali dapat menjadi penyebab kesejahteraan hidup setelah menyadari dan berusaha membina kerukunan, keseimbangan dan hubungan baik dalam pawongan, parahyangan dan palemahan (Pradana dan Pratiwi, 2021). Pawongan merupakan zonasi dimana setiap orang Bali dapat membina hubungan baik dengan sesamanya dan orang lain. Berbeda dengan Parahyangan merupakan zonasi dimana orang Bali dapat membina hubungan spiritual, sebagaimana membina hubungan baik dengan sumber hakekat sang pencipta, pemelihara sekaligus pelebur semesta. Zonasi dimana orang Bali bisa membina dan merawat lingkungan alamiah secara fisik dikenal dengan palemahan.

Filosofi Tri Hita Karana merupakan bagian kearifan lokal Bali yang telah diadaptasi dalam pembangunan pariwisata Bali. Astuti dkk (2019) mengemukakan bahwa selama ini penerapan nilai Tri Hita Karana dalam merancang model pariwisata Bali sudah efektif. Esensi Tri Hita Karana dianggap sebagai kearifan lokal yang benarbenar merupakan pengembangan ekowisata berbasis keaslian budaya lokal dalam mengembangkan desa wisata dimana pedesaan itu sendiri adalah asal mula budaya dengan kearifan lokalnya bukan di perkotaan atau internasional.

Lagut dan Suryawan (2018) mengatakan bahwa kondisi Danau Beratan pada tahap pengembangan wisata berbasis Tri Hita Karana tergolong sangat baik. Parwati dan Trianasari (2016) menyatakan bahwa pemahaman dan komitmen masyarakat tentang wisata edukasi berbasis Tri Hita Karana termasuk dalam kategori baik. Apalagi media promosinya sudah berhasil dirancang, yaitu berupa brosur forum kesenian, brosur desa wisata, dan draft buku panduan wisata edukasi berbasis Tri Hita Karana.

Kusuma dkk (2019) mengemukakan bahwa tidak terdapat pengaruh yang signifikan manfaat ekonomi pariwisata terhadap kesuksesan, kebahagiaan dan kepuasan hidup masyarakat dalam keberlanjutan pariwisata. Disatu sisi, pariwisata berbasis Tri 
Hita Karana yang diyakini mengandung nilai universal terbukti efektif dalam meningkatkan kontribusi ekonomi terhadap kepuasan masyarakat Bali dalam perkembangan pariwisata.

Dalam perkembangan pariwisata Bali, Megantari dan Suryasih (2020) menegaskan bahwa objek wisata Alas Kedaton telah melakukan pengelolaan wisata yang sesuai dengan prinsip Tri Hita Karana. Berdasarkan hasil evaluasi pengelolaan wisata menunjukan bahwa aspek pawongan masih kurang baik dan aspek parahyangan maupun palemahan telah tergolong sangat baik. Ginaya dkk (2019) menyatakan masih diperlukannya revitalisasi, transformasi, konservasi dan aktualisasi nilai-nilai kearifan lokal dalam Tri Hita Karana sebagai upaya perjuangan mewujudkan multiplier effect dalam pengembangan desa wisata berbasis masyarakat.

Aplikasi Filosofi Tri Hita Karana dalam pembangunan pariwisata Bali terbukti efektif dalam ekowisata berbasis kearifan lokal, wisata edukasi berbasis Tri Hita Karana dan pengelolaan obyek wisata danau beratan. Hal itu diantaranya menginspirasi civitas akademika IPBI dalam aplikasi Filosofi Tri Hita Karana untuk pemberdayaan masyarakat kelurahan Tonja dalam perkembangan pariwisata Bali. Usulan kegiatan program lingkungan hijau, bersih dan sehat tercipta berdasarkan kebutuhan dosen IPBI yang berelasi dengan masalah pariwisata, masalah di masyarakat dan kesiapan civitas akademika IPBI. Usulan kegiatan program pengabdian masyarakat berfokus pada pembinaan lingkungan hijau, bersih dan sehat mengingat keasrian serta kebersihan masih menjadi masalah lingkungan kelurahan Tonja sekaligus suatu masalah dalam pengelolaan daya tarik destinasi wisata. Sebagaimana disebutkan bahwa masalah lingkungan dapat menjadi masalah dalam kemajuan perkembangan pariwisata (Pradana, 2019).

Sejalan dengan perkembangan pariwisata Bali, rancangan program lingkungan hijau, bersih dan sehat disusun berdasarkan pertimbangan filosofi Tri Hita Karana karena masyarakat Tonja sudah sangat mengenal hakekat filosofi Tri Hita Karana. Selain itu, luaran kegiatan program lingkungan hijau, bersih dan sehat dalam rangka pengabdian kepada masyarakat bisa berkontribusi pada perkembangan pariwisata Bali dan bermakna bagi pemberdayaan masyarakat Tonja. Suatu rancangan teraplikasi optimal ketika sasaran, kapasitas dan kontribusi telah sesuai harapan. Demikian hakekat filosofi Tri Hita Karana ini tesirat pada bagian susunan usulan kegiatan program lingkungan hijau, bersih dan sehat di kelurahan Tonja, Denpasar yang diharapkan dapat teraplikasi maksimal untuk pemberdayaan masyarakat Tonja dalam perkembangan pariwisata dan berimplikasi terhadap tingkat kesejahteraan.

Kegiatan program lingkungan hijau, bersih dan sehat terselenggara selama dua hari di kelurahan Tonja, Denpasar dengan harapan dapat lebih kondusif untuk perkembangan pariwisata Bali. Aplikasi program lingkungan hijau, bersih dan sehat yang melibatkan civitas akademika IPBI dan masyarakat Tonja merefleksikan penerapan filosofi Tri Hita Karana. Praktik secara ideologis dapat merefleksikan prinsip filosofis (Pradana dkk, 2016). Aplikasi prinsip palemahan terlihat jelas pada judul program kegiatan pengabdian masyarakat di kelurahan Tonja. Selain itu, kegiatan penanaman bibit tanaman hias dan kegiatan bersih-bersih pekarangan di Tonja mencerminkan orientasi nilai palemahan. Sedangkan pada kegiatan diskusi tentang pariwisata Bali, bersih-bersih di Tonja yang melibatkan civitas akademika dan masyarakat Tonja beserta perwakilan dari kelurahan, pengurus adat dan pemangku pura di kelurahan Tonja terwujud sejalan dengan orientasi nilai pawongan. Sejalan dengan 
orientasi nilai parahyangan, kegiatan program lingkungan hijau, bersih dan sehat dilakukan dengan tahapan persembahyangan bersama dan pemberian donasi untuk kesucian pura dan peningkatan kualitas kebersihan area pura di kelurahan Tonja, Denpasar.

\section{SIMPULAN}

Program kegiatan pariwisata diapresiasi positif oleh masyarakat Tonja dalam usulan program pariwisata dan pemberdayaan masyarakat berorientasi Tri Hita Karana yang dirancang civitas akademika IPBI. Kegiatan pemberdayaan masyarakat Tonja dirancang dengan pertimbangan filosofi Tri Hita Karana dalam bentuk program lingkungan hijau, bersih dan sehat untuk masyarakat Tonja ditengah pembangunan pariwisata Bali.

Realisasi rancangan kegiatan pemberdayaan masyarakat Tonja berdasarkan pemahaman filsafat Tri Hita Karana dalam dinamika pembangunan pariwisata Bali dilakukan melalui kegiatan bersih-bersih fisik, sosialisasi kebutuhan kegiatan wisata, pemberian sumbangan alat kebersihan dan bibit tanaman serta melakukan persembahyangan bersama di Pura Beji, Pura Puseh dan Pura Dalem kelurahan Tonja sebagai usaha untuk mewujudkan lingkungan kelurahan Tonja yang bersih, hijau dan sehat.

\section{DAFTAR PUSTAKA}

Aziz, Moh. Ali, Sokhi Huda. (2020). Problem Semantis dan Solusi Pemahaman Multiculturalism, Interculturalism dan Crosscultural. Jurnal Masyarakat dan Budaya, 22(3), 33-47.

Berg, Bruce L., Howard Lune. (2018). Qualitative Research Methods For The Social Sciences. Vivar, Malaysia : Pearson.

Dewi, Anggraeni Purnama. (2016). Komodifikasi Tari Barong di Pulau Bali, Seni Berdasarkan Karakter Pariwisata. Panggung, 26(3), 223-233.

Endaswara, Suwardi. (2003). Metodologi Penelitian Sastra. Yogyakarta : Pustaka Widyatama.

Holub, Robert C. (2003). Reception Theory : a Critical Introduction. London : Methuen. Humaedi, M. Alie, Sri Sunarti Purwaningsih, Letsu Vella Sundary, Rusydan Fathy. (2021). Membangun Kegotongroyongan dan Mengaktifkan Peran Kepemimpinan Lokal : Strategi Pentahelix Penanganan Dampak Covid-19. Jurnal Masyarakat dan Budaya, 23(1), 39-58.

Hyland, Angus, Steven Bateman. (2014). Symbol. China : Laurence King Publishing. IPBI. (2021, april). Campus Achievement of The International Institute of Tourism and Business. Diunduh dari : https://www.ipb-intl.ac.id/ tanggal 2 mei 2021.

Johana, Kornelia, Dani Setiadarma, Kurnia Dewi Wijaya. (2020). Strategi Komunikasi Pemasaran 10 Destinasi Pariwisata Prioritas "Bali Baru" di Kementrian Pariwisata Republik Indonesia. Jurnal Ekonomi dan Manajemen Sistem Informasi. 1(6), 631- 648. 
Litabmas. 2017. Laporan Pengabdian Kepada Masyarakat : Program Lingkungan Hijau, Bersih, Sehat Untuk Mengaplikasikan Konsep Tri Hita Karana Dalam Pengembangan Pariwisata di Desa Tonja, Denpasar (Laporan). Denpasar : STPBI.

Muis, Early Wulandari, Heksa Biopsi Puji Hastuti. (2020). Menjaga Sehat, Menjaga Adat : Praktik Pengobatan Traditional Tumpuroo dan Pelestarian Adat di Hukaea-Laeya. Jurnal Masyarakat dan Budaya, 22(3), 15-31.

Patton, Michael Quinn. (2015). Qualitative Research and Evaluation Methods. London : Sage Publications.

Pradana, Gede Yoga Kharisma, Komang Shanty Muni Parwati. (2017). Local-WisdomBased Spa Tourism in Ubud Village of Bali, Indonesia. Russian Journal of Agricultural and Socio-Economic Sciences, 8(68), 188-196.

Pradana, Gede Yoga Kharisma, Komang Trisna Pratiwi Arcana. (2020). Balinese Traditional Homestay in a Sustainable Tourism Entering Millennial Era. Journal of Xi'an University of Architecture and Technology, 12(3), 4208-4217.

Pradana, Gede Yoga Kharisma, Komang Trisna Pratiwi Arcana. (2020a). Hasil Pengelolaan Homestay Bercorak Budaya Tradisional Bali Ditengah Pengaruh Perkembangan Trend Millennial di Sektor Pariwisata. Jurnal Ilmiah Hospitality Management, 11(1), 1-12.

Pradana, Gede Yoga Kharisma. (2012). Diskursus Fenomena Hamil di Luar Nikah dalam Pertunjukan Wayang Joblar. Online Journal of Cultural Studies, 1(2), 1127.

Pradana, Gede Yoga Kharisma. (2018). Implications of Commodified Parwa Shadow Puppet Performance For Tourism in Ubud, Bali. Journal of Business on Hospitality and Tourism, 4(1), 70-79. DOI: http://dx.doi.org/10.22334/jbhost.v4i1.103.g111.

Pradana, Gede Yoga Kharisma. (2019). Sosiologi Pariwisata. Denpasar : STPBI Press.

Pranajaya, I Kadek. (2019). Peran Arsitek Dalam Meraih Tri Hita Karana Tourism Awards Pada Rancangan The Ulin Villa \& SPA di Seminyak-Bali. Jurnal Patra, $1(2), 68-73$.

Rideng, I Wayan, I Nyoman Putu Budiartha, I Nyoman Sukandia. (2020). The Development of Bali Tourism Through Cultural and Local Wisdom of Customary Village. International Journal of Entrepreunership, 24(5), 1-6.

Ruastiti, Ni Made, I Wayan Suharta, Manik Suryani. (2015). Designing the Ederly Janger Dance Model in Tonja Village Denpasar. Mudra, 31(3), 378-383.

Syah, Ahmad Mujafar, Dini Hajarrahmah. (2019). Approaches to Indonesia Culture Tourism Policy : Stakeholders Perspectives on The Cultural Tourism Governances in Bayan. E-Journal of Tourism, 6(2), 178-195.

Tejayadi, I Putu Windhu, I Nengah Laba, Gede Yoga Kharisma Pradana. (2019). The Effect of Organizational Culture on Employee Satisfaction in Mercure Resort Sanur Bali Hotel. International Journal of Green Tourism Research and Applications, 1(1), 63-72.

Triguna, Ida Bagus Gede Yudha. (2004). Teori tentang Simbol. Denpasar : Widya Dharma. 